\title{
Analysis of The Impact of Financial Performance on Company Value with Corporate Social Responsibility and Good Corporate Governance as Moderating Variables
}

Muhammad Sulhan

Faculty of Economics, Maulana Malik Ibrahim State Islamic University, Indonesia sulhan@manajemen.uinmalang.ac.id

Ahmad Sidi Pratomo

Faculty of Economics, Maulana Malik Ibrahim State Islamic University, Indonesia

\begin{abstract}
Today every company is trying to maximize the value of its company. Disclosure of company information is expected to be able to maximize the value of the company, including Good Corporate Governance (GCG), Corporate Social Responsibility (CSR), Financial Performance of the Company. The purpose of this study is to find out that CSR and GCG as moderating variables can strengthen or weaken the significance of the effect of financial performance (profitability, size, leverage, slack resources, and institutional ownership) on company value. This type of research is explanatory research; the population in this study are all Pharmaceutical companies listed on the Indonesia Stock Exchange (IDX). Determination of the sample is done using the purposive sampling method. Data analysis uses Moderated Regression Analysis (MRA) with the help of SPSS software. The results of this study indicate. First, Financial Performance profitability, size, leverage, and slack resources have a significant effect on company value in pharmaceutical companies. Second, CSR and GCG variables can strengthen the influence of Financial Performance that is proxied by profitability, size, leverage, slack resources, and institutional ownership of company value in pharmaceutical companies listed on the IDX.
\end{abstract}

Keywords: Financial Performance, firm Value, CSR, GCG

\section{INTRODUCTION}

Today every company is trying to maximize the value of its company which can be reflected in its share price. This is due to the high value of the company, which will indicate prosperity for high shareholders as well. So investors will invest their capital in the company. Investors need comprehensive, accurate and timely information in making decisions to invest their capital. Disclosure of company information is expected to be able to maximize the value of the company including Good Corporate Governance (GCG), Corporate Social Responsibility (CSR), Financial Performance of the Company, and others. This information disclosure is used to support investors in making rational decisions so that the results obtained are as expected.

One of the disclosures of company information that can affect the achievement of company value is information on the application of GCG (Tumirin, 2018). The 
implementation of GCG is expected to be able to monitor company managers to be more productive and efficient in managing the company so that it can improve company performance and can increase the company's stock price as an indicator of company value. The mechanism of Good Corporate Governance (GCG) covers various things, such as the number of the board of commissioners, the independence of the board of commissioners, the size of the board of directors, and the existence of an audit committee. One indicator of the GCG mechanism that is often used is an independent commissioner. This is because the existence of this commissioner can carry out supervisory duties and provide advice to directors effectively and provide added value to the company (Novrianti, 2012)

Implementation of corporate social responsibility programs and disclose both in the annual report, and a sustainability report is a form of information needed by investors to make decisions related to company performance following the values in the community. The disclosure is to reflect the level of corporate accountability, responsibility, and transparency to investors and stakeholders. The disclosure aims to establish a good and useful communication relationship between the company and the public and other stakeholders about how the company has integrated corporate social responsibility (CSR) in every aspect of its operations (Darwin, 2017).

Several studies have analyzed factors such as company size, leverage, ownership structure considered related to the level of corporate social responsibility disclosure and show inconsistent results. Belkaoui and Karpik (1989); Ahmad, Hassan, and Mohammad (2013); and Brammer and Pavelin (2016) found a negative influence between leverage variables and voluntary disclosures. However different opinions expressed by Purnomosidhi (2015); Barako, Hancock and Izan (2006) which states that leverage has a positive influence on voluntary disclosure. Studies that examine company size for CSR disclosure show inconsistent results. Research conducted by Cowen et al. (1987); Belkaoui and Karpik (1989); Purnomosidhi (2015); Brammer and Pavelin (2016); Barako, Hancock and Izan (2006) and Reverta (2009) found size had a positive effect on voluntary disclosure. However Ahmad, Hassan, and Mohammad (2013) found that size did not affect CSR disclosure.

Studies that examine the effect of ownership concentration on CSR disclosure show inconsistent results. Research conducted by Brammer and Pavelin (2016) found that the more concentrated the share ownership of a company, the more likely it was to disclose CSR. However, a different opinion is expressed by Reverte (2009) which states that the concentration of ownership has a negative effect on CSR disclosure. While some research results that analyze the effect of environmental responsibility on the financial value of a company, for example, were conducted by Guenster et al. (2005) which documented the positive influence of social and environmental disclosure (proxied by eco-efficiency) on Tobin's q companies. Curcio and Wolf (1996) the results of their study stated that corporate performance that is responsible for the environment affects the value of the company.

Some of the descriptions above indicate the lack of consistency of research results, so it becomes exciting research about the influence of financial performance variables

164 Management and Economics Journal (MEC-J)

Vol 4 (2) August 2020 
(profitability, size, leverage, slack resources, and institutional ownership) on the value of the company with CSR and GCG as this moderating variable. The formulation of the problem is, First, whether financial performance (profitability, size, leverage, slack resources, and institutional ownership) has a significant effect on firm value; Second, whether CSR and GCG as a moderating variable can strengthen or weaken the significance of the effect of financial performance (profitability, size, leverage, slack resources, and institutional ownership) on firm value.

\section{THEORETICAL REVIEW}

\section{Good Corporate Governance (GCG)}

Good Corporate Governance (GCG) is a principle that directs and controls a company in order to achieve a balance between strength and authority of the company in providing accountability to shareholders in particular, and stakeholders in general. This is intended to regulate the authority of Directors, managers, shareholders and other parties associated with the development of the company in a particular environment.

The basic principles of GCG General Guidelines for Good Corporate Governance in Indonesia are as follows (Tumirin, 2018):

a. Transparency

Transparency is information disclosure, both in the decision-making process and in disclosing material and relevant information about the company. Corporate transparency must provide stakeholders with complete, accurate and timely information. Furthermore, if the principle of transparency is implemented appropriately and adequately, it will be able to prevent conflicts of interest of various parties in the company.

b. Accountability

Accountability is the clarity of functions, structures, systems and accountability of company organs so that the management of the company is carried out effectively. The duties and functions of the company are needed as a mechanism of management checks and balances. Some forms of implementation of the principle of accountability include effective internal audit practices, and clarity of functions, rights, obligations, authority and responsibilities in the company's articles of association.

c. Responsibility

Corporate responsibility is conformity (compliance) in the management of the company with sound corporate principles and applicable laws and regulations. The application of this principle is expected to make the company realize that in its operational activities, it often results in negative externalities (outside the company's activities) that must be borne by the community.

d. Independency

Independence is a condition in which a company is managed professionally without conflict of interest and influence/pressure from any party that is contrary to applicable laws and regulations and sound corporate principles. Independence is 
essential in the decision-making process in order to produce objective decisions for the company.

e. Fairness

Fairness is the fair and equal treatment in fulfilling stakeholder rights that arise based on agreements and applicable laws and regulations. Fairness also includes the clarity of stakeholder rights based on the legal system and enforcement of regulations to protect the rights of investors, especially minority shareholders, from various forms of fraud.

\section{Corporate Social Responsibility (CSR)}

Corporate Social Responsibility (CSR) is a company's commitment to contribute to the development of a sustainable economy focusing on the balance between economic, social and environmental aspects. CSR theory arises as a correction from Friedman (1962) single bottom line theory which states that the company is only responsible to shareholders, so the company is racing to make profits to maximize the prosperity of shareholders by carrying out unethical activities. This opinion was opposed by Freeman (1984) that stakeholders are groups or individuals who can influence the achievement of company goals. Freeman and Elkington (1998) then developed the concept of a triple bottom line to unite economic, social and environmental principles in an integrated understanding of corporate social and environmental responsibility. The existence of this concept implies that companies are not just looking for profit as much as possible, but also must make a positive contribution to the people (people) and take an active part in preserving the environment (planet).

Tsoutsoura (2014) revealed the benefits of CSR information disclosure by profit-seeking companies based on three interests, first the company's interests, second the interests of non-owner investors, third the national interests. Therefore, CSR disclosure is seen as a way to influence the perception of a company's financial prospects according to the views of external stakeholders, especially financial stakeholders (stock analysts, capital markets and institutional investors). Gray et al. (1995) state that corporate social responsibility (CSR) disclosure is described as the availability of financial and nonfinancial information about an organization's interactions with its physical and social environment. The company considers CSR activities and disclosures in the hope that good relations will be created with the company's stakeholders.

\section{Company Financial Performance}

Variables - financial performance variables that can affect company value and are also determinants of CSR and GCG disclosure were consisting of profitability, size (company size), leverage, slack resources, and institutional ownership (Ulupui, 2017).

Heinze (1976) in Hackston and Milne (1996) states that profitability is a factor that gives freedom and flexibility to management to express social responsibility to shareholders. This means the higher the profitability level of the company, the greater the disclosure of social information by the company. In contrast, the size of the company in various theories proved to be a significant factor in explaining differences in the level of 
information disclosure which would later have an impact on the value of the company (Purnomosidhi, 2015) and Brammer and Pavelin (2016).

Furthermore, leverage shows the proportion of the use of debt to finance company investment. Public companies in Indonesia are very dependent on creditors. Freeman (1984) states that creditors are one of the primary stakeholders (the leading provider of company resources) and are stakeholder power that must be considered. Thus, it can be concluded that the more a company relies on debt funding to fund its projects, the higher the level of the response given by management to the expectations of creditors for the company's role in carrying out social responsibility activities (Cornell and Shapiro, 1987).

Slack Resources can be defined as the availability of excess resources beyond the minimum level of resources needed to maintain the integrity of the organization. Slack resources owned by the company can be used to fulfil obligations to shareholders and will be less likely to get pressure from other financial stakeholders such as creditors. Thus, CSR implementation is expected to be able to reduce the desires of corporate stakeholders. Finally, financial performance variables that affect company value and are also determinants of CSR and GCG disclosure are institutional ownership, namely ownership of shares by parties in the form of institutions, such as banks, insurance companies, investment companies, pension funds and other institutions. With the control of majority shares, the institution can monitor management policies in a more significant manner compared to minority shareholders. The concentration of ownership can be an internal mechanism of management discipline, and increase the effectiveness of monitoring. Substantial ownership causes shareholders to have access to information that is significant enough to offset the benefits of information owned by management (Hubert and Langge, 2002) if this can be realized moral hazard actions management in the form of hiding information can be reduced.

\section{Hypothesis}

Research hypotheses in this study are as follows. First, financial performance (profitability, size, leverage, slack resources, and institutional ownership) has a significant effect on firm value; Second, CSR and GCG as moderating variables can strengthen the significance of the effect of financial performance (profitability, size, leverage, slack resources, and institutional ownership) on firm value

\section{METHODOLOGY}

This type of research is explanatory research, research that seeks to explain the impact (influence) of financial performance on the value of companies with CSR and GCG as moderating variables with a quantitative approach based on the financial statements of pharmaceutical companies listed on the Indonesia Stock Exchange from 2015 until 2017. 
Determination of the sample is done using the purposive sampling method. The selected pharmaceutical companies are as follows in Table 1.

Table 1. List of research samples

\begin{tabular}{cl}
\hline No & \multicolumn{1}{c}{ Company name } \\
\hline 1 & PT Darya-Varia Laboratoria Tbk (DVLA) \\
2 & PT Kalbe Farma Tbk (KLBF) \\
3 & PT Sido Muncul Tbk (SIDO) \\
4 & PT Kimia Farma (Persero) Tbk (KAEF) \\
5 & PT Merck Tbk (MERK) \\
6 & PT Pyridam Farma Tbk (PYFA) \\
7 & PT Indofarma (Persero) Tbk (INAF) \\
8 & PT Taisho Pharmaceutical Indonesia Tbk (SQBI) \\
9 & PT Tempo Scan Pacific Tbk (TSPC) \\
\hline
\end{tabular}

The variables used in this study consisted of independent variables, dependent variables, and moderation variables. The independent variables as a proxy of the Company's Financial Performance in this study are profitability, leverage, institutional ownership, size (company size), and slack resources. While the dependent variable in this study is Firm Value. The moderation variables in this study are CSR and GCG.

Data analysis in this study uses Moderated Regression Analysis (MRA) with the help of SPSS (Statistical Program for Social Science) software to test the hypothesis in this study.

To test hypothesis 1

To see the direct effect of financial performance (profitability, size, leverage, slack resources, and institutional ownership) on Company value, the equation is as follows:

$$
\begin{aligned}
& \text { NP = bo + b1 Profit + b2 Size + b3 Lev + b4 SR + b5 KI } \\
& \text { Where: NP = Company Value } \\
& \text { Profit = Profitability } \\
& \text { Lev = Leverage } \\
& \mathrm{KI} \mathrm{=} \mathrm{Institutional} \mathrm{Ownership} \\
& \text { Size = Company Size } \\
& \text { SR = Slack Resources } \\
& \text { bo = Constant } \\
& \text { b1, b2, b3, b4, b5 = Regression Coefficient }
\end{aligned}
$$

To test hypothesis II

To find out CSR and GCG as a moderating variable can strengthen the significance of the effect of financial performance (profitability, size, leverage, slack resources, and institutional ownership) on company value is as follows :

$$
\begin{aligned}
& \text { NP = bo + b1 Profit + b2 Size + b3 Lev + b4 SR + b5 KI + b6 CSR + b7 GCG } \\
& \text { Where: NP = Company Value }
\end{aligned}
$$




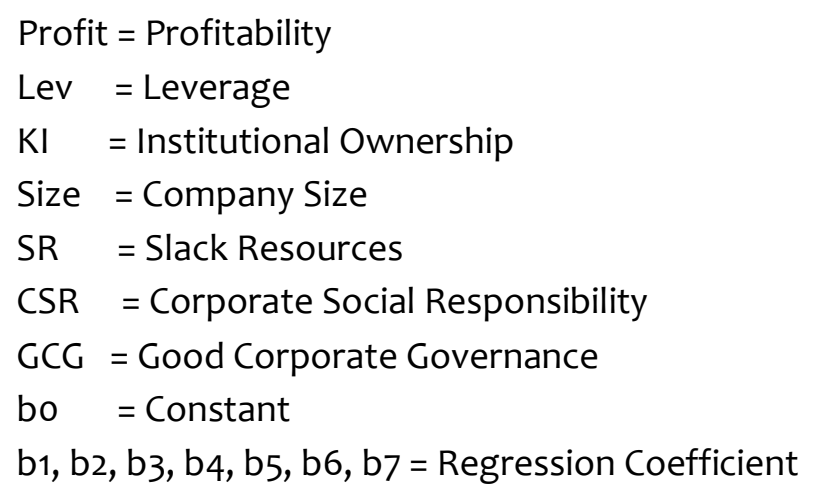

\section{RESEARCH RESULTS}

The results of the analysis of equation I data to see the direct effect of financial performance (profitability, size, leverage, slack resources, and institutional ownership) on firm value using SPSS version 17 software produced the following regression equation:

$N P=493020,937+64891,044$ Profit $+37298,633$ Size $+850,970$ Lev $+359010,710$ SR + $8,926 \mathrm{E}-7 \mathrm{KI}$

Table 2. Results of regression equation I

\begin{tabular}{llllll}
\hline No & Variable & $\begin{array}{l}\text { Regression } \\
\text { Coefficient }\end{array}$ & t-value & Sig & Information \\
\hline 1. & Profit & 64891.044 & 1.791 & .048 & significant \\
2. & Size & 37298.633 & 2.291 & .032 & significant \\
3. & Lev & 850.970 & 1.866 & .047 & significant \\
4. & SR & 359010.710 & 2.140 & .044 & significant \\
5. & KI & $8.926 \mathrm{E}-7$ & .542 & .593 & not significant \\
\hline
\end{tabular}

Table 3. Results of regression equation II

\begin{tabular}{lllcll}
\hline No & Variable & $\begin{array}{l}\text { Regression } \\
\text { Coefficient }\end{array}$ & t-value & Sig & Information \\
\hline 1. & Profit & 65149.180 & 1.944 & .046 & significant \\
2. & Size & 38295.924 & 2.390 & .031 & significant \\
3. & Lev & 879.271 & 1.983 & .047 & significant \\
4. & SR & 459003.792 & 2.293 & .034 & significant \\
5. & KI & $8.959 \mathrm{E}-7$ & .467 & .646 & not \\
& & & & & significant \\
6. & CSR & 100062.639 & 2.501 & .022 & significant \\
7. & GCG & 173619.332 & 2.660 & .017 & significant \\
\hline
\end{tabular}


Based on Table 2 it can be seen that the sig value ( $p$-value) of profitability variable is 0.048 , size (company size) is 0.032 , leverage is 0.047 , and slack resources is 0.044 . The sig value ( $p$-value) of the four variables is smaller than $a=0.05$; this means that the variable profitability, size, leverage, and slack resources have a significant effect on firm value. While institutional ownership does not have a significant effect on firm value, this is due to the sig ( $p$-value) of institutional ownership of 0.593 higher than $\alpha=0.05$. The results of the analysis of equation II data to find out CSR and GCG as a moderating variable can strengthen the significance of the influence of financial performance (profitability, size, leverage, slack resources, and institutional ownership) on company value.

\section{DISCUSSION}

\section{Effect of financial performance on company value}

The company is always trying to maintain the excellence of its business in increasing the value of the company. In the long run, the company can develop the company and reduce the economies of scale of the business. The optimization of company value which is the company's goal can be achieved through the implementation of financial management functions, where one financial decision is taken will affect other financial decisions and have an impact on the company's value (Fama and French, 1998). Fama (1978) in Wahyudi and Pawestri (2006) states that the value of the company will be reflected in its share price.

The results of this study support the research of Ulupui (2017), Sudarma (2014) and Carlson \&Bathala (1997) that financial performance (ROI and ROE) significantly influences company value. Modigliani and Miller in Ulupui (2017) state that the value of a company is determined by the earning power of the company's assets. Positive results indicate that the higher the earning power, the more efficient the asset turnover and or the higher the profit margin the company gets. This has an impact on increasing the value of the company. Research conducted by Ulupui (2017) found results that ROA has a significant positive effect on stock returns for the next period. Therefore, ROA is one of the factors that influence the value of the company. Sudarma (2014) and Carlson and Bathala (1997) also found that profitability (ROA) had a positive effect on company value.

\section{The Influence of Financial Performance on Firm Value with CSR and GCG as Moderation Variables}

Business is no longer only focused on the company's economic problems, but also social and environmental problems that arise as a result of the company's operations. The concept of sustainability requires management to improve company performance in terms of economic performance, social performance, as well as environmental preservation. It can be producing environmentally friendly products, reducing pollution caused by the production process, and exploiting nature in an environmentally friendly 
manner, treating waste (recycling waste), increasing expenditure- social expenditure (social costs) and other ways to maintain environmental balance (Purnomosidhi, 2015).

The reciprocal relationship between the community, companies, government and other stakeholders is a practical necessity. For this reason, corporations and communities have a symbiotic relationship between mutualism (Tsoutsoura, 2014). The existence of the company is expected to have benefits, such as opening employment, paying taxes, creating economic seepage patterns, helping surrounding communities and the like (Purnomosidhi, 2015). Even though a company has paid taxes to the state, it does not mean that it has lost its responsibility for public welfare. The company's activities carry economic consequences, for that sometimes the trade of being an inseparable part of corporate policy.

The results of this study support research conducted by Spicer (1978), Shane and Spicer (1983), Guenster et al. (2005) which states that there is a positive influence between environmental disclosure (proxied eco-efficiency) on Tobin's q companies, Curcio and Wolf (1996) the results of his study state that there is an influence of corporate performance that is environmentally responsible for the value of the company and Tsoutsoura (2014) states that there is an influence of corporate philanthropy on the company's financial performance.

Besides, this study also supports the results of the study of Tumirin (2018) stating that the implementation of GCG will affect the achievement of company value. Companies must certainly ensure to investors that the funds they invest in the financing, investing and growing the company are used appropriately and efficiently as well as ensuring that management is acting in the best interests of the company. The mechanism of Good Corporate Governance (GCG) covers many things, for example, the number of the board of commissioners, the independence of the board of commissioners, the size of the board of directors, and the existence of an audit committee. With the existence of one of these GCG mechanisms, it is expected that monitoring of company managers can be more productive so that it can improve company performance and company value. So if the company implements a GCG system, it is expected that the company's performance will improve for the better, so that with the increase in company performance it is also expected to increase the company's stock price as an indicator of company value.

\section{CONCLUSION}

Based on the results of data analysis and discussion of research results, it can be concluded as follows, First, Financial Performance profitability, Size (company size), Leverage, and slack resources have a significant effect on firm value in pharmaceutical companies listed on the IDX, only the ownership variable Institutional alone does not have a significant effect on firm value. This indicates that if the Financial Performance variables above have increased, it will have an impact on increasing the value of the company which is reflected in the price of shares of pharmaceutical companies listed on the IDX; Second, CSR and GCG variables can strengthen the influence of Financial Performance that is proxied by profitability, size, leverage, slack resources, and institutional ownership of firm value in pharmaceutical companies listed on the IDX. The 
implication of this research for investors is that investors should invest their funds on the stock exchange must be selective by paying attention to companies that do CSR and apply GCG properly, because CSR disclosure and good corporate governance implementation will impact to firm value reflected in the company's stock price. Suggestions for further researchers should add other variables that have not been included in this research related to firm value other than CSR and GCG. Researchers can also add industrial sectors listed on the Stock Exchange, so that the research results obtained are more comprehensive.

\section{REFERENCES}

Ahmad, H. \& Mohammad. (2013). Determinants of Environmental Reporting in Malaysia, International Journal of Business Studies, 11 (1), 69-90.

Barako,D,G.,Hancock,P.,dan Izan, H.Y. (2006). Factors Influencing Voluntary Corporate Disclosure by Kenyan Companies. Journal Compilation, 14 (2), 107-125

Belkaoui. A, and Karpik. P.G. (1989). Determinants of the Corporate Decision to Disclose Social information. Accounting, Auditing and Accountability Journal, 1(1).

Brammer, S. \& Pavelin, S. (2016). Voluntary Environmental Disclosure by Large UK Companies. Journal of Business Finance and Accounting, 33 (7-8),1168-1188.

Carlson dan Bathala. (1997). An empirical examination of the relationship between profitability and Value Firm. Academy Management Journal, 27, 42-56.

Cornell, B. and Shapiro, A. (1987). Corporate Stakeholders and Corporate Finance. Financial Management,16, 5-14. http://www.jstor.org/stable/3665543.

Cowen, S.S., Ferreri, L. B dan Parker, L.D. (1987). The Impact of Corporate characteristics on social responsibility disclosure: a typology Frequency-based analysis. Accounting, Organization and Society 12(2),11-22.

Curcio dan Wolf. (1996). The impact of corporate social responsibility in shareholder wealth. Academy of Management Journal.

Darwin. (2017). A Study of Environmental disclosure practices of Australian corporations. Accounting and Business Research, 26(3), 187-199.

Fama, E. (1987). The effect of a firm's Investment and Financing Decision on the Welfare of its Security Holders. American Economic Review, 68 (3), $272-84$.

Fama, E F and French, K. R. (1998). Taxes, Financing

Friedman. (1962). Stockholders and Stockholders: A new perspective on corporate on corporate governance. Californian Management Review, 25(2), 88-106. 
Freeman dan Elkington. (1998). Business Ethics, Corporate Good Citizenship and the Corporate Social Policy Process: A View from The United States. Journal of Business Ethics, 8, 583-595.

Freeman, R.E. (1984). Strategic Management: A Stakeholder Approach. Pitman, Massachusetts.

Guenster. N., Jeroen, D., Rob, B., and Kees, K. (2005). The Economic Value of Corporate Eco-Efficiency. Academy of Management Conference Paper. Netherlands.

Gray R. Kouhy, R dan Lavers, S. (1995). Corporate Social and Environmental Reporting: A Review of The Literature and a Longitudinal Study of UK Disclosure. Accounting, Auditing and Accountability Journal, 8(2),47-77.

Hackson and J. Milne (1996). Some Determinants of Social and Environmental Disclosures in New Zealand Companies. Accounting, Auditing, Accountability Journal, 9(1), 77-107.

Hubert dan Langge. (2002). The Impact of Environmental Management on Firm Performance. Management Science, 42(8),1199-1214.

Novrianti, V. \& Riadi, A. (2012). Pengaruh Corporate Social Responsibility dan Good Corporate Governance terhadap Kinerja Perusahaan (StudiPada Perusahaan Manufaktur di BEI Tahun 2009-2011). Jurnal Akuntansi, 1 (1), Oktober 2012.

Purnomosidhi, B. (2015). Analisis Empiris Terhadap Determinan Praktek Pengungkapan Modal Intelectual pada Perusahaan Publik di BEJ, Malang. Disertasi Universitas Brawijaya Malang.

Reverta. (2009). Factors Influencing Corporate Social and Ethical Reporting: Moving on From Extant Theories. Accounting, Auditing and Accountability Journal, 15(2), 223250.

Shane, P. and Spicer, B. (1983). Market Response to Environmental Information Produced Outside the Firm. The Accounting Review, 58(3), 521-38.

Spicer, B. (1978). Market risk, Accounting data and Companies'pollution control records. Journal of Business Finance and Accounting, 5(1).

Sudarma, M. (2014). Pengaruh profitabilitas, factor Intern dan Faktor Ekstern Terhadap Struktur Modal dan Nilai Perusahaan, Studi pada Industri yang Go Publik di BEJ. Malang. Disertasi . Universitas Brawijaya.

Tsoutsoura. (2014). Corporate Social Responsibility and Firm Financial Performance. Accounting Management Journal, 31(4), 854-872.

Tumirin. (2018). Analisis Penerapan Good Corporate Governance dan Nilai Perusahaan. Jurnal BETA, 6(1). 
Ulupui. (2017). An empirical examination of the relationship between corporate social responsibility and profitability. Academy of management journal, 28(2),446-463.

Wahyudi and Pawestri (2006). Implikasi Struktur Kepemilikan Terhadap Nilai Perusahaan dengan Keputusan Keuangan sebagai variable Intervening. Simposium Nasional Akuntansi 9 Padang, 23-26 Agustus 2006. blog.umy.ac.id. 